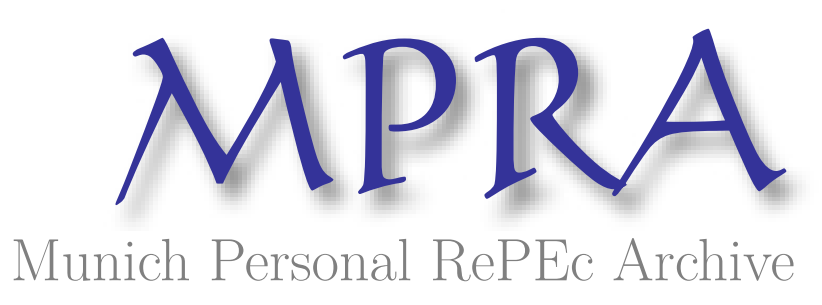

\title{
Inequality and fractionalization
}

Casey, Gregory P. and Owen, Ann L.

Hamilton College

August 2010

Online at https://mpra.ub.uni-muenchen.de/25493/

MPRA Paper No. 25493, posted 28 Sep 2010 20:16 UTC 


\title{
Inequality and Fractionalization
}

\author{
Gregory P. Casey \\ Hamilton College
}

\author{
Ann L. Owen* \\ Hamilton College
}

August 2010

\begin{abstract}
We present evidence that ethnic fragmentation explains variations in per capita income, institutions, and schooling better than income inequality when both are treated as endogenous. To do so, we identify instruments for ethnic fractionalization and income inequality based on historical experience. Using instrumental variables estimation, we find that ethnic fractionalization explains the level of income both when income inequality is included as a control in the estimation and when it is not. However, we find no evidence that income inequality affects the level of income when ethnic fractionalization is properly treated as an endogenous variable. We have similar findings when other development outcomes such as schooling or proxies for institutional quality are used as dependent variables. These results are robust to various controls and changes in the sample size and suggest that some of the previous findings regarding the effect of income inequality on development should be attributed to ethnic fractionalization.
\end{abstract}

Key words: inequality; ethnic fractionalization; colonization

JEL Codes: O15, O43

*Corresponding author: 198 College Hill Road, Clinton, NY 13323, aowen@ hamilton.edu, 315-8594419, fax: 315-859-4477. 


\section{Introduction}

A large literature finds a role for income inequality in affecting economic development both in the presence of credit market imperfections and without. The channels through which income inequality have been posited to work are numerous. For example, in a seminal paper, Galor and Zeira (1993) show that inequality can affect human capital accumulation. Moreover, Persson and Tabellini (1994) show how inequality can affect physical capital accumulation via a demand for redistributive policies, Alesina and Perotti (1996) argue that inequality affects physical capital investment through its effect on political instability, and Banerjee and Newman (1993) demonstrate a role for income inequality in affecting occupational choice and the extent of entrepreneurship. More recently, others have linked inequality to the development of low quality institutions as the political elite block institutional reform that would benefit the country as a whole but challenge their own dominance (e.g. Acemoglu, Johnson and Robinson 2005; Engerman and Sokoloff, 1997; 2000). ${ }^{1}$

At the same time, others have focused on the negative impact of a related but different aspect of society_ethnic fractionalization. Easterly and Levine (1997) show the negative consequences of ethnic diversity in African development and argue that too much fractionalization interferes with the provision of growth promoting public goods. Others have confirmed the consequences of ethnic fractionalization (Alesina et al. 2003) but Alesina and La Ferrara (2005) argue that ethnic diversity only has negative consequences in democracies where the lack of ability to coordinate across different ethnic groups may have more severe consequences. Importantly for our work, Alesina et al. (2003) and Alesina and La Ferrara (2005) also argue that ethnic diversity is endogenous and careful examinations of the role of ethnic diversity in affecting economic outcomes must take that into account. In addition, Engerman and Sokoloff (2000) argue that ethnic diversity may have also played a role in the development of institutions by allowing the elites to readily identify a group that could be excluded from privileges such as landholding or suffrage. Thus, ethnic fractionalization may have negative impacts on development

\footnotetext{
${ }^{1}$ See Galor (2009ab) for brief and comprehensive treatments of the literature on inequality and growth.
} 
independent of the level of economic inequality. Indeed, their work highlights two potential roles of ethnicity in political development: it can be a tool for identification or a potential ideological fault line. Thus, a priori, it is unclear whether ethnic differences or income inequality in general are both playing independent roles in long run post-colonial development.

In spite of a strong theoretical foundation for the effects of inequality on development, robust empirical evidence has been difficult to find. Forbes (2000) finds that inequality has a positive effect on growth while Banerjee and Duflo (2003) find an inverted U relationship between growth rates and changes in the income distribution. Furthermore, they argue that it is difficult to interpret any of these correlations causally because of difficult identification problems. In an effort to address the identification issue, Easterly (2001a, 2007) uses characteristics of the land that might support plantationbased economies as instruments for inequality. He concludes that inequality is associated with lower levels of income, schooling and quality of institutions. Importantly, Easterly (2007) uses a variety of control variables, including ethnic fractionalization (treated as an exogenous variable), to demonstrate that income inequality is a robust determinant of the level of income per capita.

In contrast to the empirical literature relating income inequality to development, there is less debate about the negative consequences of ethnic fractionalization, at least in certain circumstances. However, few researchers treat ethnic fractionalization as an endogenous variable even though there are clear theoretical reasons to believe that it is. In a related paper, Michalopoulos (2008) identifies geographic causes of fractionalization but does not relate fractionalization to income per capita. While treating ethnic fractionalization as exogenous may be an appropriate specification in classic growth regressions spanning 30 or so years, it is less acceptable over the longer time spans implicit in income level regressions (Alesina et al., 2003). Specifically, most migration occurs into those countries with higher levels of economic and institutional development, implying that OLS coefficients will underestimate the negative impacts of ethnic diversity (Mayda, 2005; Freeman, 2006). Moreover, ethnic diversity may hinder the development of institutions and provisions of public goods while countries are in the early stages of development, but have a smaller (or non-existent) negative impact once the 
institutions of democracy and rule of law have been implemented (e.g. Easterly, 2001b). Thus, to best determine the role of ethnic fractionalization in development, we need to find instruments for both fractionalization and inequality.

This paper exploits differences in land endowments to identify appropriate instruments for ethnic fractionalization. Specifically, we use the likelihood that a country would develop plantations based on the suitability for cultivating sugar versus wheat. As pointed out by Engerman and Sokoloff, certain crops were associated with the use of slaves because of economies of scale that were realized in producing them on large slave plantations. Thus the qualities of the land in colonial times have implications for the ethnic makeup of the population today. Along the same line, we add tropical location and a commodity exporting dummy in later regressions. Because all of these variables have been used as instruments for inequality for similar reasons (e.g., Easterly; 2001b; 2007) the dimension of inequality captured by these instruments is correlated with the dimension of fractionalization captured by the same instruments Thus, an important question is: Is it income inequality in general that affects development or is it ethnic fractionalization?

In answering this question, we find that ethnic fragmentation is an important determinant of per capita income, school enrollment and institutional quality. Most importantly, we demonstrate that, when income inequality and ethnic fractionalization are simultaneously added as endogenous variables in such regressions, ethnic diversity has a negative and significant effect while income inequality enters insignificantly and often with a positive coefficient. These results are robust to numerous controls and restricting the sample to only former colonies. The results also clearly indicate that fractionalization must be treated as an endogenous variable.

These results are important because, although income inequality and ethnic fractionalization may be correlated empirically, the channels through which ethnic fractionalization affect economic development may be different than those through which income inequality affects economic growth. There are policy implications to this finding as well: the best policy to remedy the deleterious effects of 
ethnic fractionalization may be very different from one aimed at alleviating the effects of income inequality.

To the extent that ethnic fractionalization is a cause of income inequality or perhaps tells us something about the nature of the inequality, our results suggest that there are certain types of inequality that are worse for economic development than others. In other words, our results are consistent with the idea that inequality that is perpetuated by ethnic divisions may be particularly bad for economic growth. In that sense, to the extent that ethnic fractionalization affects growth via political or institutional channels rather than via factor accumulation, our findings complement those who argue that political inequality may lead to instability or lack of cohesion which lowers growth (e.g., Perotti, 1996; Rodrik, 1999; Alesina et al, 2006, Easterly and Woolcock, 2006). Also, our findings are consistent with the arguments in the strand of the inequality and growth literature that links inequality to the development of low quality institutions if exploiting ethnic divisions is a way for the elite to maintain their economic and political power when faced with growing domestic agitation for equal rights or when balancing inconsistencies inherent in arguing for freedom from colonizing powers while promoting the continuance of slavery (e.g. Engerman and Sokoloff, 2000; Benn, 2004).

Our results are developed in the next 3 sections. Section 2 provides more background on the ways in which previous literature suggests that ethnic fractionalization affects development outcomes, Section 3 presents our empirical results and Section 4 concludes.

\section{Related Literature}

Engerman and Sokoloff $(1997 ; 2000)$ argue that colonies suitable for the production of profitable commodities with economies of scale, like sugar or mining, developed more unequal plantation-type societies. According to the theory, this system allowed the entrenched economic elite to prevent institutional development, voting rights and public education. The model is not formal, leaving room for the competing effects of ethnicity and income inequality; although the focus is on the latter.

The Engerman and Sokoloff theory serves as the motivation for the empirical work by Easterly (2001a, 
2007), who uses natural endowments as instruments in regressions demonstrating the harmful effects of inequality on per capita income, institutional quality and public school provision. The Easterly results also demonstrate that fractionalization has a negative impact on these various development outcomes, though it is treated as exogenous.

The literature on ethnic fractionalization and development outcomes is lengthy. Empirical research shows that ethnic diversity leads to lower growth, per capita income and public good provision as well as poorer quality government institutions and policies (e.g. Easterly and Levine, 1997; La Porta et al, 1999; Alesina et al., 2003). The standard story is that different ethnic groups cannot agree on a set of institutions and public goods because they have different preferences, leading to an under provision of necessary government actions. This may entail differences in the types of goods (e.g. roads versus schools) or the orientation of certain goods (e.g. where to put the new road) (e.g. Alesina, Baqir and Easterly, 1999; Alesina and La Ferrara, 2005). Another argument is that ethnically divided groups will resist necessary reforms in an attempt to ensure that other groups bear the majority of the costs (e.g. Alesina and Drazen, 1991; Rodrik, 1999). Still another option is that ethnic heterogeneity permits greater social sanctioning, leading to more effective outcomes in situations resembling prisoners' dilemma (e.g. Miguel and Gugerty, 2005).

Most of these potential mechanisms rely on the rational economic calculation in decision making processes. A very different perspective is that people have preferences over ethnic groups. In this case, people will not want to support any public good or institution that would benefit another ethnic group, even though they would support the exact same measure if it supported a member of their own group. For example, Poterba (1997) shows that older whites in US cities are less likely to provide public education when the beneficiaries are minority children. Similarly, Alesina, Glaeser and Sacerdote (2001) find that differences in ethnic heterogeneity help explain the differing levels of redistribution in Europe and America.

The history of suffrage is replete with examples of voting qualifications based on race. Ethnic division may affect political transitions in multiple ways. First, it may play a role within strategic 
decision making of the elites. For example, some studies have modeled the transition from dictatorship to democracy as a way for elites to commit to future redistribution and avoid revolution, which would place even greater danger on their privileged economic position (e.g. Acemoglu and Robinson, 2000, 2001b). Within this context, elites could better their position by extending voting rights only to those members of their same ethnic group, lowering the total future redistribution needed to prevent revolution. At the same time, the lower class of the dominant ethnic group would benefit from the redistribution in the same way as before, but also gain an advantage over competitors in securing the benefits of increased political power. For example, the competition for political patronage or future high-skill jobs for the next generation would be greatly reduced. In this case, ethnic differences would merely serve as a convenient way to identify and divide groups of people.

\section{Empirical Results}

Our goal is to show that the dimension of inequality that is associated with ethnic fractionalization better explains poor growth performance than income inequality in general. To provide convincing empirical results, we will base our specifications on earlier empirical work demonstrating the link between inequality and growth (Easterly, 2001a, 2007). As mentioned in the introduction, our contention is that the forces that led to inequality also led to ethnic fractionalization. In particular, earlier literature attempts to identify geographic instruments that lead to inequality by providing incentives to develop plantations, which bred both inequality and ethnic divisions. Our departure from previous literature which leads us to different conclusions is that we will treat both fractionalization and inequality as endogenous variables.

\subsection{First Stage Results}

First, we show that, in addition to predicting income inequality, land quality also predicts ethnic fractionalization. For our main instrument, we will use the likelihood that a country would export sugar or wheat. Specifically, the variable, LWHEATSUGAR, is defined as $\log (1+$ area of land suitable for 
growing wheat/1+area of land suitable for growing sugar). This data originally comes from the United Nations' Food and Agriculture Organization (FAO 2005). Easterly (2007) demonstrates that LWHEATSUGAR is significantly correlated with two measures of inequality: the percent of income controlled by the top 20\% (INCSHARE) and the Gini coefficient (GINI), which are taken from the WIDER (2000) database. Both are averaged over the period of 1960-1998 in order reduce measurement error and are adjusted to account for biases introduced by different survey measurement techniques.

Columns 1 and 2 of Table 1 replicate the Easterly (2007) results re income inequality and Column 3 of Table 1 shows that we obtain similar results when we use LWHEATSUGAR to predict ethnic fractionalization. The measure of fractionalization, originally from Alesina et al (2003), is the likelihood that two randomly selected individuals will be from different ethno-linguistic groups. The results in Table 1 suggest that a one standard deviation increase in LWHEATSUGAR decreases fractionalization, income share and the Gini coefficient by $.36, .44$, and .41 standard deviations respectively. The R-squared values for each simple regression in Table 1 are similar and, given the theoretical reasons to link land quality to both income inequality and ethnic fractionalization, this suggests that land quality may be an equally good instrument for both inequality and fractionalization. In the next section, we confirm this supposition.

\subsection{Testing the Effects of Inequality and Fractionalization Separately}

First, we present the estimation results of the effects of fractionalization and inequality when land quality is used as an instrument for each in separate regressions in Panel A of Table 2. Columns 1 and 4 present results when the gini coefficient and the income share of the top 20 percent are used as measures of inequality and the dependent variable is the log of per capita income in $2002 .^{2}$ These results replicate those in Easterly (2007). However, in column 7 we report results when we substitute fractionalization for inequality and find that fractionalization also has the expected negative effect on income per capita.

\footnotetext{
${ }^{2}$ We use the log of income per capita in 2002 so that our results can be directly compared to those in Easterly (2007).
} 
As mentioned earlier, two ways in which inequality and fractionalization have been hypothesized to affect growth is via the accumulation of human capital or via the development of institutions. To see if there is evidence for these channels in our data we also report similar regressions in Table 2, using a measure of human capital accumulation and institution quality. So our results can be comparable to the previous literature we again use the same variables employed by Easterly (2007), $k k z 02$, an aggregate measure of institutional quality from Kauffman, Kraay and Zoibo (2002) and secondary school enrollment rates averaged from 1998-2002 (sec9802). These results appear in the remaining columns of Table 2 and show that in all cases, both inequality and fractionalization are significantly and negatively associated with institutional quality and schooling enrollments.

In Panel B of Table 2, we repeat the estimations results after adding the share of arable land in the tropics (tropical) as a second instrument in order to perform over identification tests. Again, the explanatory variable is significant at the $1 \%$ level in all nine regressions and, more importantly, fractionalization passes the over identification test in all three regressions; the tests fails to reject the null hypothesis that LWHEATSUGAR and tropical are uncorrelated with the error term and are correctly excluded from each of the estimated equationsOf course, the same can be said for 5 of the 6 regressions with inequality as the explanatory variables. We also present the p-values and F-statitistics from the first stage regressions in order to ensure that the instruments are actually significant predictors of the fractionalization and inequality. Again, the results suggest that the natural endowments predict significant variation in both instrumented variables.

So, we have found that ethnic fractionalization and income inequality present equally plausible explanations for why the historical experience of countries as "plantation economies" is associated with slower growth than that experienced by their counterparts. One way to get a relative sense of which may be more important is to compare the size of the coefficients. Table 3 shows the relative effects of a one standard deviation change in ethnic diversity and income inequality for each dependent variable based on the results in panel A of table 2. Although ethnic fractionalization has the highest impact for all three dependent variables, the results are similar enough that it would be premature to draw any conclusions. 
Thus, to sort out the relative importance of ethnic fractionalization vs. income inequality, we move on to an alternative approach, adding control variables from the previous literature: a commodity exporting indicator variable, the share of arable land in the tropics, legal heritage, and continent dummies. Easterly (2007) demonstrates that the results for income inequality are robust to all of the following, and we do not replicate his results in order to conserve space. Our results for similar estimations using ethnic fractionalization appear in Table 4. In 11 of the 12 specifications, ethnic fractionalization is significant at the $5 \%$ level or better. When using income per capita as the dependent variable and adding tropical as a control, FRAC is significant at the $10 \%$ level (p-value of .06). These results continue to suggest that income inequality and ethnic fractionalization could each have important effects on long-run development. ${ }^{3}$

\subsection{The "Horserace"}

Since both fractionalization and income inequality appear to be important determinants of longrun development when investigated separately, we now enter them simultaneously into instrumental variables regressions. As we noted earlier, the two variables are correlated and the reason for similar results when using each one separately may be that one is proxying for the other. This "horserace" technique allows us to determine which variable exerts a greater effect and is similar to the approach taken by Acemoglu and Johnson (2005), Rodrik Subramanian and Trebbi (2004), and Easterly and Levine (2003) who attempt to determine the relative importance of competing factors that could influence growth.

To run this test, we need multiple instruments. Unfortunately, multicolinearity prevents us from identifying the results when we use only LWHEATSUGAR and tropical. Thus, we looked to earlier empirical work related motivated by the potential link between institutions and inequality to find a third

\footnotetext{
${ }^{3}$ We also explored using the number of times a country had an internal conflict over the period 1946-2008. We found that adding this control variable did not materially affect our conclusions about the impact of ethnic fractionalization, but the control variable itself did not consistently enter the estimations in a statistically significant way. Data was from the Centre for the Study of Civil War web site: http://www.prio.no/CSCW/Datasets/Armed-Conflict/UCDP-PRIO/Armed-Conflicts-Version-X-2009/
} 
instrument. Specifically, we use a commodity exporting dummy (commod), which Easterly (2001a) uses as an instrument for inequality in similar regressions. The theory is identical to that motivating the use of LWHEATSUGAR, specifically that commodity exporting can lead to plantation economies. Thus, the three instruments related to the previous work are LWHEATSUGAR, commod and tropical; however, to separate the effects of ethnic fractionalization and inequality, we need to generate sufficient variation between the two. To help with this process, we make a slight departure from Easterly 2007 and substitute the absolute value of latitude for tropical. We combine these three instruments for inequality (latitude, commod and LWHEATSUGAR) to test the relative effects of inequality and ethnic fractionalization. Thus, our specification is as follows:

$$
\begin{aligned}
& \text { FRAC }_{i}=\beta_{11} \text { LWHEATSUGAR }_{i}+\beta_{12} \text { latitude }_{i}+\beta_{13} \text { Commod }_{i}+\varepsilon_{i} \\
& \text { INEQ }_{i}=\beta_{21} \text { LWHEATSUGAR }_{i}+\beta_{22} \text { latitude }_{i}+\beta_{23} \text { Commod }_{i}+\omega_{i} \\
& y_{i}=\gamma_{1} \text { FRAC }_{i}+\gamma_{2} \text { INC }_{i}+\boldsymbol{\delta} \boldsymbol{Z}_{i}+\mu_{i}
\end{aligned}
$$

where INEQ is either the income share of the richest quintile or the gini coefficient, $y$ is the log of the level of income per capita, school enrollment rate or the KKZO2 measure of institutional quality, and $\boldsymbol{Z}$ is a vector of control variables. All results are confirmed (but not shown) when using tropical instead of latitude to fully embed our results in the earlier work.

Table 5 presents the base results. In Panel A, the Gini coefficient is the measure of inequality. Column 1 demonstrates that ethnic fractionalization has a negative impact on the log of income per capita and that this relationship is significant at the $1 \%$ level. However, the Gini coefficient has an insignificant and positive coefficient. The next two columns add legal heritage and continent dummies as controls, which do not alter the main results. The overidentification tests indicate that the instruments can be safely excluded from the second stage regressions. Similarly, the first stage results indicate a strong correlation between the natural endowments and both fractionalization and inequality. The results are similar when using the institutional quality index as the dependent variable, except that fractionalization is just insignificant at the $5 \%$ level when no controls are added, and inequality always has a negative sign. The final three columns use schooling as the dependent variable. Fractionalization is 
significant at the $1 \%$ level in all specifications while the Gini coefficient is insignificant and positive. The results are very similar in panel B, which uses INCSHARE instead of GINI. Thus, the results indicate that ethnic diversity exerts a more robust effect on long-run development than does income inequality.

Why are our results different from those found by previous authors? The main difference in our approach is that we treated ethnic fractionalization as an endogenous variable in the estimation of income per capita. As we argued earlier, changes in income per capita can induce migration over the long-run which would affect the ethnic diversity of a country's population. If high income induced migration which produced greater diversity, treating ethnic diversity as exogenous causes the coefficient on ethnic diversity to be biased upwards, counteracting the hypothesized negative effect of ethnic fractionalization on income.

Importantly, we are able to test the exogeneity assumption (for both income inequality and fractionalization) statistically. The test statistic for, say, fractionalization is the difference in the Sargent-Hansen statistic when fractionalization is treated as endogenous and when it is treated as exogenous. The null hypothesis is that the variable in question can actually be treated as exogenous. The results clearly support the contention that fractionalization must be treated as an endogenous variable. We can reject the null hypothesis at the $5 \%$ level in 5 of the 6 regressions where lgdppc is the dependent variable and at the $1 \%$ level whenever sec9802 is the dependent variable. When KKZO2 is the dependent variable, the null hypothesis can only be rejected in 4 of the 6 regressions. Interestingly, the results consistently state that we can treat income inequality as an exogenous variable, a specification which we will discuss later. It is important to remember, however, that the use of IV to identify the effects of income inequality is not primarily motivated by concerns over reverse causality. Rather, "structural" and "market-based" inequality may have very different effects. Thus, we continue to treat inequality as endogenous is most of the remaining specifications.

To build on these results, Table 6 splits up the individual governance indicators that comprise kkz02: measures of "voice and accountability" (voice2002), "political stability" (polstab2002), 
“government efficiency" (govteff2002), "regulation quality" (regqual2002), "rule of law" (rulelaw2002) and "corruption" (corrupt2002). Fractionalization is negative and significant in 15 of the 18 specifications, suggesting that ethnic diversity has a negative effect on all of the different aspects of "good governance" comprising the aggregate index. The correlation is especially strong when using rulelaw2002, regqual2002 or govteff2002. Also, FRAC is found to be endogenous is half of the specifications, including specifications for all of the dependent variables except for polstab2002. This implies that migration occurs towards countries with higher governance scores for all other measures, though it is difficult to tease out the specific reasons for migration due to correlation between different measures as well as correlation between good governance, income levels and schooling. Inequality, on the other hand, is never significant, though it always has the expected negative sign. Once again, it is never found to be endogenous.

The use of our instruments is motivated by the experiences of former European colonies. While extending the sample to include all countries is beneficial because it enlarges the sample size and makes our work comparable to others, it is also important to confirm that the results hold when we restrict the sample to only former colonies. We do so in table 7 . The results are very similar, except that fractionalization is significant at lower levels of confidence, likely due to the substantial decrease in sample size. Specifically, FRAC is significant in all but four of the eighteen specifications. In all regressions where schooling is the dependent variable, ethnic diversity is significant at the $5 \%$ level. Inequality is consistently insignificant with inconsistent signs. Once again, the overidentification tests do not indicate any problems with the validity of the instruments, but the first stage results are not always significant. This is likely a result of the substantial decrease in sample size. Also, the endogeneity tests confirm the argument that fractionalization must be treated as an endogenous variable.

Finally, we re-test our main results when treating inequality as exogenous. The implications are similar to all of the evidence presented earlier. FRAC is significant at the $1 \%$ level in all regression while inequality is highly insignificant with inconsistent signs. Again, this is not our preferred specification because it blurs the effects of "structural" and "market-based" inequality. The results do 
confirm, however, the major finding of this paper, namely that fractionalization better explains long run development than income inequality.

\section{Discussion}

While this paper has focused on comparing the effects of inequality and ethnic fractionalization, we view our results as complementary to the growing literature on the "structural" effects of income inequality (e.g. Acemoglu, Johnson and Robinson, 2005; Engerman and Sokoloff, 2000; Easterly, 2007). This literature focuses on how inequality prevents the emergence of political systems that provide basic market-supporting institutions and public goods because the elites resist such institutions. Thus, the economic elites use their power to protect their own position at the expense of total economic growth.

A long literature on ethnic fractionalization suggests similar outcomes emerging through similar but distinct mechanisms. Specifically, different factions struggle to ensure that the allocation of government resources disproportionately benefit their own side. This struggle prevents countries from solving collective action problems and undercuts the validity and effectiveness of existing government institutions by spurring (in reality or perception) ethnic groups to use them in a partial manner. Thus, inequality prevents the emergence of high quality institutions because the people who control the development of their own political and economic institutions do not want to allow others to close the gap by improving their own position. Ethnic diversity, on the other, leads to a struggle between competing factions that can lead to worse economic outcomes even if one group does not have complete control over the governmental resources. As in the inequality literature, the importance of ethnic diversity in long-run development works through the "structural" factors that prevent countries from developing appropriate market-supporting institutions and public goods due to the existence of incentives for certain actors that are misaligned with the optimal social outcomes.

We provide evidence that ethnic fractionalization has a greater effect on economic development than income inequality. This does not imply that inequality has no effect; rather, the existing data (using the previously identified instruments) suggest that fractionalization has a stronger effect and that high 
income inequality is not sufficient condition to lead to worse economic outcomes. Technically, our major addition to the literature is to treat ethnic fractionalization as endogenous.

In addition to showing that ethnic fractionalization affects the level of income, we show that it also affects investment in schooling. In our estimations, ethnic fractionalization has a strong negative effect on secondary school enrollment rates, while inequality has an insignificant and often positive impact. This result challenges the notion that elites will simply restrict access to public goods in order to maintain their privileged position. There are several reasons why elites may not block access to public education based simply on income differences. First, income differences could be insufficient motivation for a person to be willing to view the success of their group or (or himself) separately from the success of a country as a whole. Second, elites may simply lack the power to restrict public good provisions based on income. Finally, recent work in developing a unified growth theory argues that elites (or at least some portion of elites) benefitted from having a more well-educated public (Galor and Moav, 2004; Galor, 2005; Golar, Moav and Vollrath, 2009). Instead, the results confirm the notion that ethnic differences prevent societies from overcoming the collective action problems inherent in providing public goods.

Another set of results suggests that ethnic fractionalization also affects income via the development of institutional quality. As above, we don't find that income inequality in general consistently affects income in a statistically significant way. The results for ethnic fractionalization, however, show many signs of persistent conflict in the development of effective institutions. These struggles manifest themselves in high levels of corruption and regulatory interference in the market and inefficient provision of services by the government bureaucracy and justice systems, all of which could result from ethnic groups attempting to use the government to extract rents from opposing segments of society. Similarly, lower scores on the "voice and accountability" measure could be the result of entrenched ethnic interests preventing real electoral competition. Finally, the relationship between ethnic fractionalization and "political stability and violence" is likely a response of the inability of diverse societies to mediate problems through established political channels. 


\section{Conclusion}

We provide evidence that ethnic heterogeneity is better able to explain differences in income levels, school enrollment rates, and institutional quality than income inequality. Our results suggest that the nature of divisions in society may be particularly important in determining the effects of inequality on development.

Differences in economic performance between former European colonies have received much attention in the literature. We have provided evidence that ethnic fractionalization, rather than income inequality in general, is the major driving force behind differing paths to political and economic development. The results also suggest that ethnic differences have an important role to play in the literature on political transition (e.g. Acemoglu and Robinson, 2000, 2001b 2006ab). These results add to a long literature identifying the negative effects of ethnic fractionalization (e.g. Easterly and Levine, 1997; Alesina et al, 2003; Alesina and La Ferrara, 2005). Indeed, our results have implications for all regressions using the level of income as the dependent variable by implying that ethnic fractionalization must be treated as endogenous.

\section{Acknowledgements}

We are grateful for helpful comments from Lewis Davis, Julio Videras, and Stephen Wu. 


\section{Works Cited}

Acemoglu, Daron, and Robinson, James, 2000. Why did Western Europe extend the franchise?: democracy, inequality, and growth in historical perspective. Quarterly Journal of Economics 115, 1167200.

Acemoglu, Daron, Johnson, Simon, and Robinson, James, 2001a. The colonial origins of comparative development. American Economic Review 91 (5), 1369-1401.

Daron Acemoglu \& James A. Robinson, 2001b. "A Theory of Political Transitions," American Economic Review, American Economic Association, vol. 91(4), pages 938-963, September

Acemoglu, Daron, Johnson, Simon, Robinson, James, 2002. Reversal of Fortune: Geography and Institutions in the Making of the Modern World Income Distribution. Quarterly Journal of Economics, Vol. 117, 1231-1294.

Acemoglu, Daron, Johnson, Simon, Robinson, James, 2005. Institutions as the fundamental determinant of long term growth. In: Aghion, Philippe, Durlauf, Steven (Eds.), Handbook of Economic Growth. Elsevier.

Acemoglu, Daron, 2005. "Politics and economics in weak and strong states," Journal of Monetary Economics, Elsevier, vol. 52(7), pages 1199-1226, October

Acemoglu,Daron \& Robinson,James A., 2006a. "Economic Origins of Dictatorship and Democracy." Cambridge University Press, Cambridge.

Acemoglu, Daron and Robinson, James, 2006b. De Facto Political Power and Institutional Persistence. American Economic Review 96(2), 325-330.

Acemoglu, Daron, and Robinson, James, 2008a. Persistence of powers, elites and institutions. American Economic Review 98:267-93.

Acemoglu, Daron and Robinson, James, 2008b. The Persistence and Change of Institutions in the Americas. Southern Economic Journal 75 (2): 282-299.

Daron Acemoglu \& Georgy Egorov \& Konstantin Sonin, 2009. "Political Selection and Persistence of Bad Governments," NBER Working Papers 15230, National Bureau of Economic Research, Inc

Daron Acemoglu \& Davide Ticchi \& Andrea Vindigni, 2009. "Persistence of Civil Wars," NBER Working Papers 15378, National Bureau of Economic Research, Inc

Daron Acemoglu \& Davide Ticchi \& Andrea Vindigni, 2010. "A Theory of Military Dictatorships," American Economic Journal: Macroeconomics, American Economic Association, vol. 2(1), pages 1-42, January.

Aghion, Philippe and Patrick Bolton, 1997. A Theory of Trickle-Down Growth and Development. Review of Economic Studies, 64, 151-172.

Alesina, Alberto., and Drazen,Allan, 1991. Why Are Stabilizations Delayed? American Economic Review, 80, 1170-1188. 
Alesina, Alberto, Baqir, Reza, and Easterly,William, 1999. Public goods and ethnic divisions. Quarterly Journal of Economics CXIV (4), 1243-1284.

Alesina, Alberto, Rodrik, Dani, 1994. Distributive politics and economic growth. Quarterly Journal of Economics 108, 465-490.

Alesina, Alberto, Ozler, Sule, Roubini, Nouriel, Swagel, Phillip, 1996. Political instability and economic growth. Journal of Economic Growth 1 (2), 189-211 (June).

Alesina, Alberto., and Spolaore, Enrico, 1997. On the number and size of nations. Quarterly Journal of Economics, CXII, 1027-1056.

Alesina, Alberto, Reza Baqir, and Caroline Hoxby. 2004. "Political Jurisdictions in Heterogeneous Communities.” Journal of Political Economy, 112(2): 348-96.

Alesina, Alberto, and Eliana La Ferrara. 2000. "Participation in Heterogeneous Communities." Quarterly Journal of Economics, 115(3): 847-904.

Alesina, Alberto, Edward L. Glaeser, and Bruce Sacerdote. 2001. "Why Doesn't the United States Have a European-Style Welfare State?” Brookings Papers Econ. Activity, no. 2, pp. 187-278.

Alesina, Alberto, and Eliana La Ferrara. 2002. "Who Trusts Others?" Journal of Public Economics, 85(2): 207-34.

Alesina, Alberto, et al, 2003. " Fractionalization," Journal of Economic Growth, Springer, vol. 8(2), pages 155-94, June.

Banerjee, Abhijit V \& Newman, Andrew F, 1993. "Occupational Choice and the Process of Development," Journal of Political Economy, University of Chicago Press, vol. 101(2), pages 274-98, April.

Benn, Denis. The Caribbean: An Intellectual History 1774-2003. Ian Randle Publishers: Miami, 2004.

Besley, Timothy and Robinson, James, 2010. .Quis Custodiet Ipsos Custodens: Civilian Control over the Military. Journal of the European Economic Association Papers and Proceedings, forthcoming.

Clarke, G.1995. "More Evidence on Income Distribution and Growth," Journal of Development Economics 47: 403-427.

Deininger, K. and L. Squire. 1998. "New ways of looking at old issues: inequality and growth,” Journal of Development Economics 57: 259-287

Easterly, William, 2001. The middle class consensus and economic development. Journal of Economic Growth 6 (4), 317-336.

Easterly, William, 2001b. Can Institutions Resolve Ethnic Conflict? Economic Development and Cultural Change, 49(4), 687-706.

Easterly, William, 2007. Inequality does cause underdevelopment: insights from a new instrument. Journal of Development Economics 84: 55-776. 
Easterly, William and Levine, Ross, 1997a. Africa's growth tragedy: policies and ethnic divisions. Quarterly Journal of Economics 152 (4), 1203-1250.

Easterly, William and Levine, Ross, 2003. Tropics, germs, and crops: the role of endowments in economic development. Journal of Monetary Economics 50 (1).

Easterly, William; Ritzen, Jozef; Woolcock, Michael, 2006. Social cohesion, institutions and growth. Economics and Politics, 18 (2), 103-120.

Easterly, W. 2007. "Inequality Does Cause Underdevelopment: Insights from a New Instrument," Journal of Economic Development 84: 755-776.

Engerman, Stanley, and Sokoloff, Kenneth, 2006. Colonialism, inequality and the long-run paths of Development. In: Benerjee, Abhijit, Benabou, Roland and Mookherjee, Dilip (Eds.), Understanding Poverty. Oxford University Press, New York, NY.

Engerman, Stanley, and Sokoloff, Kenneth, 2000. Institutions, factor endowments and paths of development in the New World. Journal of Economic Perspectives 14 (3): 217-232.

Engerman, Stanley, Sokoloff, Kenneth, 1997. Factor endowments, institutions, and differential paths of growth among new world economies: a view from economic historians of the United States. In: Haber, Stephen (Ed.), How Latin America Fell Behind. Stanford University Press, Stanford CA.

Engerman, Stanley L., Sokoloff, Kenneth L, 2005. "The evolution of suffrage institutions in the Americas," Journal of Economic History 65 (4), 891-921.

Freeman, Richard, 2006. People Flows in Globalization. Journal of Economic Perspectives, 20, 145170.

Galor, Oded. and Moav, Omer, 2004, "From Physical to Human Capital Accumulation: Inequality and the Process of Development," Review of Economic Studies 71: 1001-1026.

Galor, Oded. and Zeira, Joseph, 1993. "Income Distribution and Macroeconomics," Review of Economic Studies 60: 35-52.

Galor, Oded. 2009a. "Inequality and Economic Development: An Overview," Working Papers 2009-3, Brown University, Department of Economics.

Galor, Oded. (ed). Inequality and Economic Development: A Modern Perspective. Edward Elgar Publishing, 2009b.

Glaeser, Edward L., David Laibson, Jose A. Scheinkman, and Christine L. Soutter. 2000. "Measuring Trust." Quarterly Journal of Economics, 115(3): 811-46.

Kaufmann, Daniel \& Kraay, Aart \& Zoido-Lobaton, Pablo, 2002. "Governance matters II - updated indicators for 2000-01," Policy Research Working Paper Series 2772, The World Bank.

La Porta, Rafael, Lopez-de-Silanes, Florencio, Shleifer, Andrei, Vishny, Robert W., 1998. Law and finance. Journal of Political Economy 106 (6), 1113-1155 (December). 
La Porta, Rafael, Lopez-de-Silanes, Florencio, Shleifer, Andrei, Vishny, Robert, 1999. The quality of government. Journal of Law, Economics, and Organization 15, 222-279.

Anna Maria Mayda, 2005. "International Migration: A Panel Data Analysis of Economic and NonEconomic Determinants," IZA Discussion Papers 1590, Institute for the Study of Labor (IZA).

Stelios Michalopoulos, 2008. "The Origins of Ethnolinguistic Diversity: Theory and Evidence," Discussion Papers Series, Department of Economics, Tufts University 0725, Department of Economics, Tufts University.

Miguel, Edward, and Mary Kay Gugerty. 2005. "Ethnic Diversity, Social Sanctions, and Public Goods in Kenya.” Journal of Public Economics, 89, 2325-2368

Persson, Torsten, Tabellini, Guido, 1994. Is inequality harmful for growth? American Economic Review $84,600-621$.

Poterba, James M. 1997. "Demographic Structure and the Political Economy of Public Education." Journal of Policy Analysis and Management, 16(1): 48-66.

Dani Rodrik \& Arvind Subramanian \& Francesco Trebbi, 2004. "Institutions Rule: The Primacy of Institutions Over Geography and Integration in Economic Development," Journal of Economic Growth, Springer, vol. 9(2), pages 131-165, 06.

World Bank, 2005.World Development Indicators, Various years.

World Institute for Development Economics Research (WIDER), 2000, World Income Inequality Database, Version 1.0. 
Table 1: Land Endowments, Inequality and Fractionalization

\begin{tabular}{|c|c|c|c|}
\hline & $(1)$ & (2) & (3) \\
\hline & GINI & INCSHARE & FRAC \\
\hline & OLS & OLS & OLS \\
\hline LWHEATSUGAR & $\begin{array}{c}-18.328 * * * \\
(3.279)\end{array}$ & $\begin{array}{c}-19.133 * * * \\
(2.992)\end{array}$ & $\begin{array}{c}-0.441 * * * \\
(0.096)\end{array}$ \\
\hline Constant & $\begin{array}{c}44.555 * * * \\
(0.923)\end{array}$ & $\begin{array}{c}49.275 \text { *** } \\
(0.798)\end{array}$ & $\begin{array}{c}0.478 * * * \\
(0.024)\end{array}$ \\
\hline Observations & 118 & 114 & 118 \\
\hline R-squared & 0.169 & 0.216 & 0.131 \\
\hline
\end{tabular}




\section{Table 2: Base Results with Inequality and Fractionalization Separate}

\begin{tabular}{|c|c|c|c|c|c|c|c|c|c|}
\hline & (1) & (2) & (3) & (4) & (5) & $(6)$ & $(7)$ & $(8)$ & (9) \\
\hline & $\operatorname{lgdppc}$ & kkz2002 & sec9802 & $\operatorname{lgdppc}$ & kkz2002 & sec9802 & $\operatorname{lgdppc}$ & kkz2002 & sec9802 \\
\hline & IV & IV & IV & IV & IV & IV & IV & IV & IV \\
\hline GINI & $\begin{array}{c}-0.121 * * * \\
(0.027)\end{array}$ & $\begin{array}{c}-0.091 * * * \\
(0.020)\end{array}$ & $\begin{array}{c}\text { Panel A: Res } \\
-4.891 * * * \\
(0.960)\end{array}$ & ts with $\mathrm{LWH}$ & ATSUGAR & is Instrument & & & \\
\hline INCSHARE & & & & $\begin{array}{c}-0.127 * * * \\
(0.029)\end{array}$ & $\begin{array}{c}-0.098 * * * \\
(0.020)\end{array}$ & $\begin{array}{c}-4.795 * * * \\
(0.876)\end{array}$ & & & \\
\hline FRAC & & & & & & & $\begin{array}{c}-4.791 * * * \\
(1.050)\end{array}$ & $\begin{array}{c}-3.798 * * * \\
(0.819)\end{array}$ & $\begin{array}{c}-184.518 * * * \\
(33.969)\end{array}$ \\
\hline Cons & $\begin{array}{c}13.030 * * * \\
(1.132)\end{array}$ & $\begin{array}{c}3.910 * * * \\
(0.847)\end{array}$ & $\begin{array}{c}278.252 * * * \\
(39.440)\end{array}$ & $\begin{array}{c}13.888^{* * * *} \\
(1.388)\end{array}$ & $\begin{array}{c}4.658 * * * \\
(0.951)\end{array}$ & $\begin{array}{c}296.781 * * * \\
(40.601)\end{array}$ & $\begin{array}{c}9.935^{* * * *} \\
(0.483)\end{array}$ & $\begin{array}{c}1.657 * * * \\
(0.359)\end{array}$ & $\begin{array}{c}149.694 * * * \\
(14.523)\end{array}$ \\
\hline Obs & 97 & 118 & 113 & 96 & 114 & 110 & 97 & 118 & 113 \\
\hline FS F-Stat & 27.419 & 31.233 & 28.800 & 31.244 & 40.896 & 37.744 & 20.486 & 21.054 & 25.480 \\
\hline FS P-Value & $0.000 * * *$ & $0.000 * * *$ & $0.000 * * *$ & $0.000 * * *$ & $0.000 * * *$ & $0.000 * * *$ & $0.000 * * *$ & $0.000 * * *$ & $0.000 * * *$ \\
\hline \multicolumn{10}{|c|}{ Panel B: Results with LWHEATSUGAR and Tropical as Instruments } \\
\hline GINI & $\begin{array}{c}-0.123 * * * \\
(0.028)\end{array}$ & $\begin{array}{c}-0.096 * * * \\
(0.021)\end{array}$ & $\begin{array}{c}-4.933 * * * \\
(0.981)\end{array}$ & & & & & & \\
\hline INCSHARE & & & & $\begin{array}{c}-0.128 * * * \\
(0.030)\end{array}$ & $\begin{array}{c}-0.098 * * * \\
(0.020)\end{array}$ & $\begin{array}{c}-4.695^{* * * *} \\
(0.848)\end{array}$ & & & \\
\hline FRAC & & & & & & & $\begin{array}{c}-4.156 * * * \\
(0.856)\end{array}$ & $\begin{array}{c}-3.446^{* * * *} \\
(0.703)\end{array}$ & $\begin{array}{c}-179.457 * * * * \\
\quad(33.222)\end{array}$ \\
\hline Cons & $\begin{array}{c}13.119 * * * \\
(1.187)\end{array}$ & $\begin{array}{c}4.117 * * * \\
(0.880)\end{array}$ & $\begin{array}{c}279.786^{* * * *} \\
(40.352)\end{array}$ & $\begin{array}{c}13.944 * * * \\
(1.411)\end{array}$ & $\begin{array}{c}4.687 * * * \\
(0.961)\end{array}$ & $\begin{array}{c}291.731 * * * \\
(39.285)\end{array}$ & $\begin{array}{c}9.639 * * * \\
(0.393)\end{array}$ & $\begin{array}{l}1.501 * * * \\
(0.315)\end{array}$ & $\begin{array}{c}146.847 * * * \\
(13.926)\end{array}$ \\
\hline Obs & 95 & 116 & 111 & 95 & 113 & 109 & 95 & 116 & 111 \\
\hline OIR & 0.6308 & 0.5885 & 0.2188 & 0.3071 & 0.3022 & $0.0835^{*}$ & 0.3215 & 0.3320 & 0.8884 \\
\hline FS F-Stat & 12.98 & 15.01 & 13.92 & 15.44 & 20.45 & 19.08 & 13.51 & 13.02 & 14.39 \\
\hline FS P-Value & $0.000 * * *$ & $0.000 * * *$ & $0.000 * * *$ & $0.000 * * *$ & $0.000 * * *$ & $0.000 * * *$ & $0.000 * * *$ & $0.000 * * *$ & $0.000 * * *$ \\
\hline
\end{tabular}

Robust standard errors in parentheses. $* * * \mathrm{p}<0.01, * * \mathrm{p}<0.05, * \mathrm{p}<0.1$. OIR is the p-value for the Hansen's J test of the exclusion restriction. FS F-Stat and FS P-Value are the F-Statistic and P-value from the first stage regression. Under the null hypothesis, the instruments can actually be treated as exogenous. GINI is the gini coefficient. INCSHARE is the income share of the richest quintile. FRAC is ethno-lingual fractionalization. $L G D P P C$ is the log of real GDP per capita in 2002. KKZ2002 is a composite measure of institutional quality. SEC9802 is the average secondary school enrollment rate over the period 1998-2002. 
Table 3: Comparing Effects using Standard Deviations

\begin{tabular}{cccc}
\hline & lgdppc & kkz02 & sec9802 \\
\hline GINI & -1.09 & -1.04 & -1.27 \\
INCSHARE & -1.1 & -1.09 & -1.2 \\
FRAC & -1.2 & -1.21 & -1.33
\end{tabular}

This table shows the effects of a one standard deviation change in the explanatory variables on the dependent variable (also in standard deviations) from table 2. GINI is the gini coefficient. INCSHARE is the income share of the richest quintile. FRAC is ethno-lingual fractionalization. $L G D P P C$ is the $\log$ of real GDP per capita in 2002. KKZ2002 is a composite measure of institutional quality. SEC9802 is the average secondary school enrollment rate over the period 1998-2002. 
Table 4: Effects of Fractionalization with Controls

\begin{tabular}{|c|c|c|c|c|c|c|c|c|c|c|c|c|}
\hline & (1) & (2) & (3) & (4) & (5) & (6) & (7) & (8) & (9) & (10) & $(11)$ & (12) \\
\hline & lgdppc & lgdppc & lgdppc & lgdppc & kkz2002 & kkz2002 & kkz2002 & kkz2002 & sec9802 & sec9802 & sec9802 & sec9802 \\
\hline & IV & IV & IV & IV & IV & IV & IV & IV & IV & IV & IV & IV \\
\hline FRAC & $\begin{array}{l}-6.561 * \\
(3.424)\end{array}$ & $\begin{array}{c}-4.479 * * * \\
(1.198)\end{array}$ & $\begin{array}{c}-5.852 * * * \\
(1.734)\end{array}$ & $\begin{array}{c}-4.406 * * \\
(1.777)\end{array}$ & $\begin{array}{c}-5.369 * * \\
(2.711)\end{array}$ & $\begin{array}{c}-4.274 * * * \\
(1.099)\end{array}$ & $\begin{array}{c}-4.888 * * * \\
(1.416)\end{array}$ & $\begin{array}{c}-4.047 * * * \\
(1.376)\end{array}$ & $\begin{array}{c}-189.036 * * * \\
(70.489)\end{array}$ & $\begin{array}{c}-182.280 * * * \\
(44.125)\end{array}$ & $\begin{array}{c}-211.173 * * * \\
(63.494)\end{array}$ & $\begin{array}{c}-132.371 * * * * \\
(36.381)\end{array}$ \\
\hline Tropical & $\begin{array}{c}0.744 \\
(1.045)\end{array}$ & & & & $\begin{array}{c}0.542 \\
(0.767)\end{array}$ & & & & $\begin{array}{c}2.928 \\
(21.722)\end{array}$ & & & \\
\hline Commodity & & $\begin{array}{l}-0.238 \\
(0.295)\end{array}$ & & & & $\begin{array}{c}0.298 \\
(0.290)\end{array}$ & & & & $\begin{array}{c}-1.510 \\
(12.558)\end{array}$ & & \\
\hline $\begin{array}{c}\text { British } \\
\text { Heritage }\end{array}$ & & & 0.784 & & & & 0.612 & & & & 31.734 & \\
\hline & & & $(0.790)$ & & & & $(0.625)$ & & & & (27.086) & \\
\hline $\begin{array}{l}\text { French } \\
\text { Heritage }\end{array}$ & & & 0.507 & & & & 0.206 & & & & 19.553 & \\
\hline Soc. Heritage & & & $\begin{array}{c}(0.643) \\
0.074 \\
(0.636)\end{array}$ & & & & $\begin{array}{l}(0.522) \\
-0.332 \\
(0.457)\end{array}$ & & & & $\begin{array}{c}(23.221) \\
18.753 \\
(18.275)\end{array}$ & \\
\hline $\begin{array}{c}\text { Middle } \\
\text { East/Africa }\end{array}$ & & & & $9.619 * * *$ & & & & $1.900 * *$ & & & & $113.956^{* * *}$ \\
\hline & & & & (1.025) & & & & $(0.796)$ & & & & $(20.577)$ \\
\hline $\begin{array}{l}\text { South \& } \\
\text { East Asia }\end{array}$ & & & & $9.388 * * *$ & & & & $1.426^{* *}$ & & & & $115.630^{* * * *}$ \\
\hline & & & & $(0.742)$ & & & & $(0.558)$ & & & & (15.699) \\
\hline $\begin{array}{c}\text { Europe/ } \\
\text { Central Asia }\end{array}$ & & & & $9.967 * * *$ & & & & $1.725^{* * *}$ & & & & $141.737 * * *$ \\
\hline & & & & $(0.533)$ & & & & $(0.458)$ & & & & $(12.050)$ \\
\hline $\begin{array}{c}\text { Western } \\
\text { Hemisphere }\end{array}$ & & & & $10.084 * * *$ & & & & $1.919 * * *$ & & & & $137.660 * * *$ \\
\hline & & & & (0.894) & & & & $(0.693)$ & & & & (17.919) \\
\hline Constant & $\begin{array}{c}10.434 * * * \\
(1.191)\end{array}$ & $\begin{array}{c}9.859 * * * \\
(0.502)\end{array}$ & $\begin{array}{c}9.894 * * * \\
(0.556)\end{array}$ & & $\begin{array}{c}2.163 * * \\
(0.949)\end{array}$ & $\begin{array}{c}1.792 * * * \\
(0.439)\end{array}$ & $\begin{array}{c}1.935 * * * \\
(0.397)\end{array}$ & & $\begin{array}{c}150.029 * * * \\
(24.694)\end{array}$ & $\begin{array}{c}149.101 * * * \\
(16.794)\end{array}$ & $\begin{array}{c}139.689 * * * \\
(14.527)\end{array}$ & \\
\hline Obs & 95 & 97 & 96 & 97 & 116 & 118 & 114 & 118 & 111 & 113 & 110 & 113 \\
\hline FS F-Stat & 3.40 & 14.95 & 9.41 & 6.64 & 3.93 & 13.74 & 9.76 & 8.51 & 6.62 & 16.06 & 9.97 & 9.92 \\
\hline FS P-Value & $0.068^{*}$ & $0.000 * * *$ & $0.003 * * *$ & $0.012 * *$ & $0.050 * *$ & $0.000 * * *$ & $0.002 * * *$ & $0.004 * * *$ & $0.011 * *$ & $0.000 * * *$ & $0.002 * * *$ & $0.002 * * *$ \\
\hline
\end{tabular}


Table 5: The "Horserace"

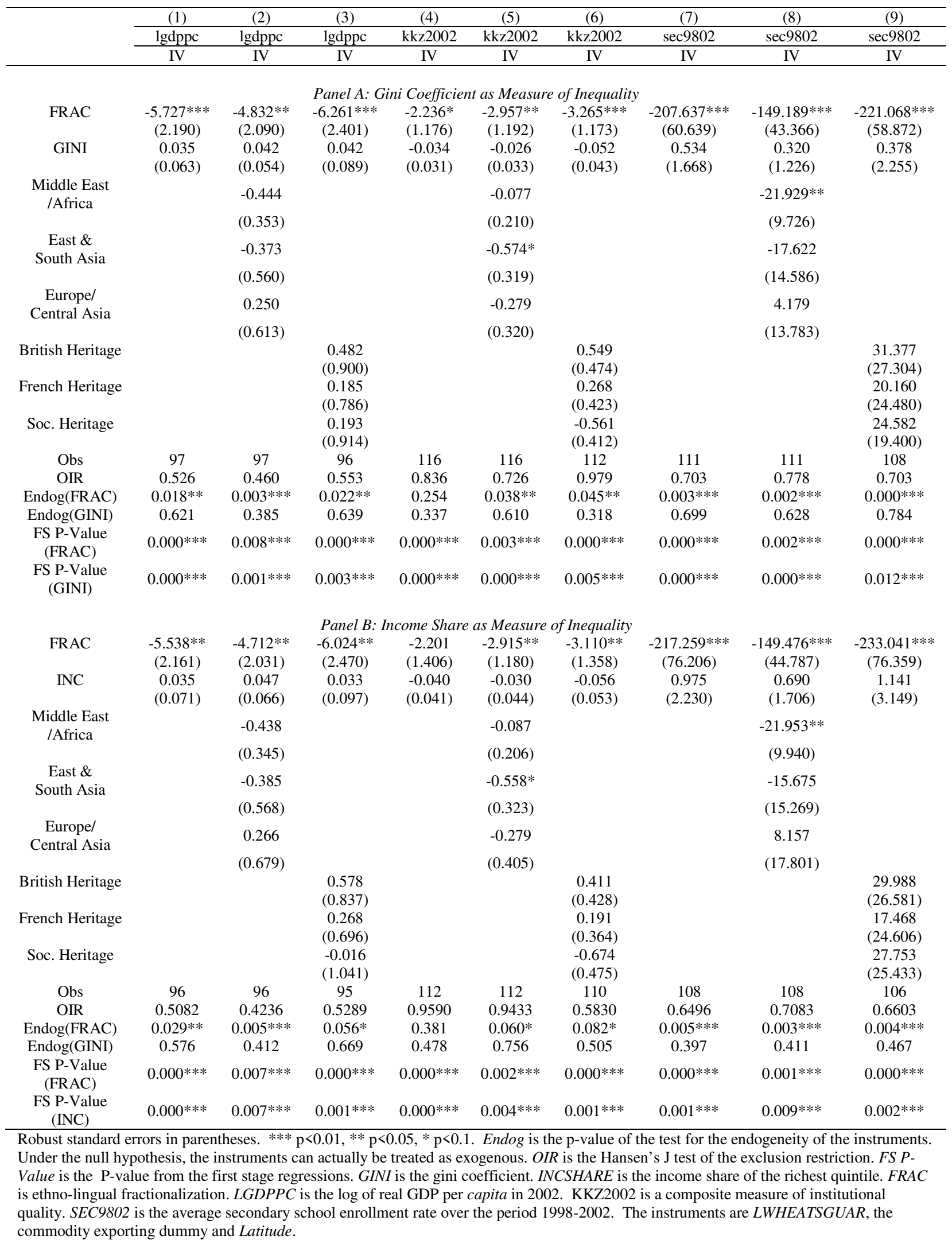


Table 6: Breaking Down Institutions

\begin{tabular}{|c|c|c|c|c|c|c|c|c|c|}
\hline & (1) & (2) & (3) & (4) & (5) & (6) & (7) & $(8)$ & (9) \\
\hline & voice 2002 & voice 2002 & voice 2002 & polstab2002 & polstab2002 & polstab2002 & rulelaw2002 & rulelaw2002 & rulelaw2002 \\
\hline & IV & IV & IV & IV & IV & IV & IV & IV & IV \\
\hline \multirow[t]{2}{*}{ FRAC } & -1.964 & $-2.506^{*}$ & $-3.329 * *$ & -2.192 & $-2.269^{*}$ & $-2.533^{*}$ & $-3.003 * *$ & $-3.854 * * *$ & $-4.317 * * *$ \\
\hline & (1.519) & (1.304) & $(1.507)$ & (1.423) & $(1.321)$ & $(1.356)$ & $(1.358)$ & $(1.439)$ & $(1.401)$ \\
\hline \multirow[t]{2}{*}{ GINI } & -0.056 & -0.046 & -0.071 & -0.050 & -0.050 & -0.052 & -0.053 & -0.039 & -0.071 \\
\hline & $(0.040)$ & $(0.039)$ & $(0.050)$ & $(0.037)$ & $(0.037)$ & $(0.046)$ & $(0.038)$ & $(0.040)$ & $(0.052)$ \\
\hline \multirow[t]{2}{*}{ Middle East/ Africa } & & $-0.548 * *$ & & & -0.298 & & & 0.136 & \\
\hline & & $(0.241)$ & & & $(0.237)$ & & & $(0.252)$ & \\
\hline \multirow[t]{2}{*}{ East Asia } & & $-1.188 * * *$ & & & $-0.744 * *$ & & & -0.595 & \\
\hline & & $(0.361)$ & & & $(0.354)$ & & & $(0.451)$ & \\
\hline Europe/ Central Asia & & $-0.590^{*}$ & & & -0.274 & & & -0.258 & \\
\hline & & $(0.357)$ & & & $(0.345)$ & & & $(0.432)$ & \\
\hline British Heritage & & & $\begin{array}{c}0.685 \\
(0.554)\end{array}$ & & & $\begin{array}{c}0.007 \\
(0.501)\end{array}$ & & & $\begin{array}{c}0.726 \\
(0.593)\end{array}$ \\
\hline \multirow[t]{2}{*}{ French Heritage } & & & 0.403 & & & -0.141 & & & 0.245 \\
\hline & & & $(0.471)$ & & & $(0.415)$ & & & $(0.520)$ \\
\hline Soc. Heritage & & & $\begin{array}{l}-0.800 * \\
(0.463)\end{array}$ & & & $\begin{array}{l}-0.472 \\
(0.367)\end{array}$ & & & $\begin{array}{l}-0.900 * \\
(0.465)\end{array}$ \\
\hline \multirow[t]{2}{*}{ Constant } & $3.269 * * *$ & $3.607 * *$ & $4.294 * * *$ & $3.000 * * *$ & $3.317 * *$ & $3.399 * *$ & $3.515^{* * *}$ & $3.427 * *$ & $4.759 * * *$ \\
\hline & $(1.177)$ & $(1.550)$ & $(1.653)$ & $(1.093)$ & $(1.511)$ & $(1.513)$ & $(1.196)$ & (1.695) & $(1.791)$ \\
\hline Observations & 116 & 116 & 112 & 116 & 116 & 112 & 116 & 116 & 112 \\
\hline OIR & 0.211 & 0.102 & 0.302 & 0.865 & 0.962 & 0.809 & 0.877 & 0.443 & 0.912 \\
\hline Endog(FRAC) & 0.335 & 0.109 & $0.038 * *$ & 0.453 & 0.398 & 0.247 & 0.144 & $0.024 * *$ & $0.007 * * *$ \\
\hline Endog(GINI) & 0.166 & 0.344 & 0.167 & 0.453 & 0.276 & 0.303 & 0.252 & 0.616 & 0.271 \\
\hline FS P-Value (FRAC) & $0.000 * * *$ & $0.003 * * *$ & $0.000 * * *$ & $0.000 * * *$ & $0.003 * * *$ & $0.000^{* * * *}$ & $0.000 * * *$ & $0.003 * * *$ & $0.000^{* * *} *$ \\
\hline $\begin{array}{l}\text { FS P-Value } \\
\text { (GINI) }\end{array}$ & $0.000 * * *$ & $0.000 * * *$ & $0.005 * * *$ & $0.000 * * *$ & $0.000 * * *$ & $0.005 * * *$ & $0.000 * * *$ & $0.000 * * *$ & $0.005^{* * * *}$ \\
\hline
\end{tabular}

Robust standard errors in parentheses. $* * * \mathrm{p}<0.01,{ }^{*} \mathrm{p}<0.05, * \mathrm{p}<0.1$. Endog is the p-value of the test for the endogeneity of the instruments. Under the null hypothesis, the instruments can actually be treated as exogenous. OIR is the Hansen's J test of the exclusion restriction. FS P-Value is the P-value from the first stage regressions. GINI is the gini coefficient. GINI is the Gini coefficient. INCSHARE is the income share of the richest quintile. FRAC is ethno-lingual fractionalization. The Instruments are LWHEATSGUAR, the commodity exporting dummy and Latitude. 
Table 6 Continued

\begin{tabular}{|c|c|c|c|c|c|c|c|c|c|}
\hline & $(1)$ & (2) & (3) & (4) & (5) & (6) & $(7)$ & $(8)$ & (9) \\
\hline & govteff 2002 & govteff2002 & govteff 2002 & regqual2002 & regqual2002 & regqual2002 & corrupt2002 & corrupt2002 & corrupt2002 \\
\hline & IV & IV & IV & IV & IV & IV & IV & IV & IV \\
\hline FRAC & $\begin{array}{c}-2.846^{* *} \\
(1.420)\end{array}$ & $\begin{array}{c}-4.046^{* *} \\
(1.621)\end{array}$ & $\begin{array}{c}-4.274 * * * \\
(1.443)\end{array}$ & $\begin{array}{c}-3.226^{* *} \\
(1.498)\end{array}$ & $\begin{array}{c}-3.590 * * \\
(1.523)\end{array}$ & $\begin{array}{c}-4.370 * * * \\
(1.503)\end{array}$ & $\begin{array}{l}-2.211 \\
(1.480)\end{array}$ & $\begin{array}{c}-4.081 * * \\
(1.624)\end{array}$ & $\begin{array}{c}-3.934 * * * \\
(1.462)\end{array}$ \\
\hline GINI & $\begin{array}{l}-0.047 \\
(0.039)\end{array}$ & $\begin{array}{l}-0.032 \\
(0.042)\end{array}$ & $\begin{array}{l}-0.074 \\
(0.055)\end{array}$ & $\begin{array}{l}-0.019 \\
(0.039)\end{array}$ & $\begin{array}{l}-0.009 \\
(0.040)\end{array}$ & $\begin{array}{l}-0.039 \\
(0.053)\end{array}$ & $\begin{array}{l}-0.063 \\
(0.041)\end{array}$ & $\begin{array}{l}-0.042 \\
(0.045)\end{array}$ & $\begin{array}{l}-0.096 \\
(0.059)\end{array}$ \\
\hline Middle East/ Africa & & $\begin{array}{c}0.163 \\
(0.272)\end{array}$ & & & $\begin{array}{l}-0.138 \\
(0.270)\end{array}$ & & & $\begin{array}{c}0.165 \\
(0.284)\end{array}$ & \\
\hline East \& South Asia & & $\begin{array}{l}-0.394 \\
(0.436)\end{array}$ & & & $\begin{array}{l}-0.616 \\
(0.408)\end{array}$ & & & $\begin{array}{c}-0.753^{*} \\
(0.455)\end{array}$ & \\
\hline Europe/ Central Asia & & $\begin{array}{l}-0.215 \\
(0.438)\end{array}$ & & & $\begin{array}{l}-0.175 \\
(0.423)\end{array}$ & & & $\begin{array}{l}-0.439 \\
(0.459)\end{array}$ & \\
\hline British Heritage & & & $\begin{array}{c}0.863 \\
(0.617)\end{array}$ & & & $\begin{array}{c}0.673 \\
(0.596)\end{array}$ & & & $\begin{array}{c}0.770 \\
(0.656)\end{array}$ \\
\hline French Heritage & & & $\begin{array}{c}0.336 \\
(0.556)\end{array}$ & & & $\begin{array}{c}0.341 \\
(0.533)\end{array}$ & & & $\begin{array}{c}0.418 \\
(0.596)\end{array}$ \\
\hline Soc. Heritage & & & $\begin{array}{l}-0.759 \\
(0.544)\end{array}$ & & & $\begin{array}{l}-0.571 \\
(0.515)\end{array}$ & & & $\begin{array}{c}-1.080^{*} \\
(0.559)\end{array}$ \\
\hline Constant & $\begin{array}{c}3.257 * * * \\
(1.156)\end{array}$ & $\begin{array}{l}3.226^{*} \\
(1.649)\end{array}$ & $\begin{array}{c}4.794 * * * \\
(1.834)\end{array}$ & $\begin{array}{c}2.285^{* *} \\
(1.140)\end{array}$ & $\begin{array}{c}2.225 \\
(1.579)\end{array}$ & $\begin{array}{l}3.416^{*} \\
(1.750)\end{array}$ & $\begin{array}{c}3.607 * * * \\
(1.245)\end{array}$ & $\begin{array}{c}3.759 * * \\
(1.785)\end{array}$ & $\begin{array}{c}5.628 * * * \\
(1.948)\end{array}$ \\
\hline Observations & 116 & 116 & 112 & 116 & 116 & 112 & 116 & 116 & 112 \\
\hline OIR & 0.714 & 0.688 & 0.836 & 0.727 & 0.666 & 0.890 & 0.848 & 0.762 & 0.989 \\
\hline Endog(FRAC) & 0.233 & $0.024 * *$ & $0.038 * *$ & 0.147 & $0.031 * *$ & $0.022 * *$ & 0.417 & $0.028 * *$ & $0.060 *$ \\
\hline Endog(GINI) & 0.375 & 0.721 & 0.324 & 0.625 & 0.970 & 0.526 & 0.175 & 0.555 & 0.165 \\
\hline FS P-Value (FRAC) & $0.000 * * *$ & $0.003 * * *$ & $0.000 * * *$ & $0.000^{* * *}$ & $0.003 * * *$ & $0.000 * * *$ & $0.000 * * *$ & $0.003 * * *$ & $0.000 * * *$ \\
\hline $\begin{array}{l}\text { FS P-Value } \\
\text { (GINI) }\end{array}$ & $0.000 * * *$ & $0.000 * * *$ & $0.005 * * *$ & $0.000 * * *$ & $0.000 * * *$ & $0.005 * * *$ & $0.000 * * *$ & $0.000 * * *$ & $0.005^{* * *}$ \\
\hline
\end{tabular}

Robust standard errors in parentheses. $* * * \mathrm{p}<0.01, * * \mathrm{p}<0.05,{ }^{*} \mathrm{p}<0.1 . \quad$ Endog is the $\mathrm{p}$-value of the test for the endogeneity of the instruments. Under the null hypothesis, the instruments can actually be treated as exogenous. OIR is the Hansen's J test of the exclusion restriction. FS P-Value is the P-value from the first stage regressions. GINI is the gini coefficient. GINI is the Gini coefficient. INCSHARE is the income share of the richest quintile. FRAC is ethno-lingual fractionalization. The Instruments are LWHEATSGUAR, the commodity exporting dummy and Latitude. 
Table 7: Development in Former Colonies

\begin{tabular}{|c|c|c|c|c|c|c|c|c|c|}
\hline & (1) & $(2)$ & (3) & (4) & (5) & (6) & $(7)$ & $(8)$ & (9) \\
\hline & lgdppc & $\operatorname{lgdppc}$ & lgdppc & kkz2002 & kkz2002 & kkz2002 & sec9802 & $\sec 9802$ & sec9802 \\
\hline & IV & IV & IV & IV & IV & IV & IV & IV & IV \\
\hline \multicolumn{10}{|c|}{ Panel A: Gini Coefficient as Measure of Inequality } \\
\hline FRAC & $\begin{array}{l}-6.296^{*} \\
(3.745)\end{array}$ & $\begin{array}{l}-5.422 \\
(3.869)\end{array}$ & $\begin{array}{l}-6.164^{*} \\
(3.587)\end{array}$ & $\begin{array}{l}-3.013^{*} \\
(1.802)\end{array}$ & $\begin{array}{l}-3.656 \\
(2.585)\end{array}$ & $\begin{array}{l}-2.755^{*} \\
(1.491)\end{array}$ & $\begin{array}{l}-182.915 * * \\
(79.528)\end{array}$ & $\begin{array}{l}-153.150 * * \\
(75.553)\end{array}$ & $\begin{array}{c}-175.638^{* *} \\
(71.797)\end{array}$ \\
\hline GINI & $\begin{array}{l}0.076 \\
(0.117)\end{array}$ & $\begin{array}{c}0.046 \\
(0.076)\end{array}$ & $\begin{array}{c}0.088 \\
(0.120)\end{array}$ & $\begin{array}{l}-0.025 \\
(0.049)\end{array}$ & $\begin{array}{l}-0.006 \\
(0.048)\end{array}$ & $\begin{array}{l}-0.021 \\
(0.046)\end{array}$ & $\begin{array}{c}0.959 \\
(2.509)\end{array}$ & $\begin{array}{c}0.044 \\
(1.584)\end{array}$ & $\begin{array}{c}1.170 \\
(2.372)\end{array}$ \\
\hline $\begin{array}{l}\text { Middle East/ } \\
\text { Africa }\end{array}$ & & -0.425 & & & 0.069 & & & $-22.325^{*}$ & \\
\hline & & $(0.557)$ & & & $(0.400)$ & & & $(13.231)$ & \\
\hline $\begin{array}{c}\text { East \& } \\
\text { South Asia }\end{array}$ & & -0.231 & & & -0.400 & & & -17.608 & \\
\hline & & $(0.638)$ & & & $(0.380)$ & & & $(16.140)$ & \\
\hline British Heritage & & & $\begin{array}{c}0.349 \\
(0.464)\end{array}$ & & & $\begin{array}{c}0.335 \\
(0.219)\end{array}$ & & & $\begin{array}{c}9.308 \\
(12.282)\end{array}$ \\
\hline Obs & 66 & 66 & 66 & 69 & 69 & 69 & 66 & 66 & 66 \\
\hline OIR & 0.991 & 0.867 & 0.938 & 0.985 & 0.980 & 0.800 & 0.548 & 0.805 & 0.480 \\
\hline Endog(FRAC) & $0.018^{* *}$ & $0.006 * * *$ & $0.015^{* *}$ & $0.087 *$ & $0.027 * *$ & $0.085^{*}$ & $0.033^{* *}$ & $0.019 * *$ & $0.027 * *$ \\
\hline Endog(GINI) & 0.417 & 0.481 & 0.313 & 0.537 & 0.922 & 0.637 & 0.549 & 0.973 & 0.360 \\
\hline FS P-Value (FRAC) & 0.135 & 0.115 & $0.044 * *$ & 0.150 & 0.128 & $0.051 *$ & $0.090^{*}$ & 0.124 & $0.031 * *$ \\
\hline $\begin{array}{l}\text { FS P-Value } \\
\text { (GINI) }\end{array}$ & 0.249 & $0.062^{*}$ & 0.193 & 0.161 & $0.039 * *$ & 0.122 & 0.232 & $0.047 * *$ & 0.175 \\
\hline \multicolumn{10}{|c|}{ Panel B: Income Share as Measure of Inequality } \\
\hline FRAC & $\begin{array}{l}-6.025 * \\
(3.459)\end{array}$ & $\begin{array}{l}-5.344 \\
(3.803)\end{array}$ & $\begin{array}{l}-5.859^{*} \\
(3.224)\end{array}$ & $\begin{array}{l}-3.058^{*} \\
(1.790)\end{array}$ & $\begin{array}{l}-3.657 \\
(2.649)\end{array}$ & $\begin{array}{l}-2.822 * \\
(1.484)\end{array}$ & $\begin{array}{c}-184.481 * * \\
(82.639)\end{array}$ & $\begin{array}{c}-153.838 * * \\
(77.875)\end{array}$ & $\begin{array}{c}-176.523 * * \\
(74.210)\end{array}$ \\
\hline INCSHARE & $\begin{array}{c}0.074 \\
(0.106)\end{array}$ & $\begin{array}{c}0.048 \\
(0.081)\end{array}$ & $\begin{array}{c}0.088 \\
(0.108)\end{array}$ & $\begin{array}{l}-0.028 \\
(0.054)\end{array}$ & $\begin{array}{l}-0.006 \\
(0.058)\end{array}$ & $\begin{array}{l}-0.022 \\
(0.052)\end{array}$ & $\begin{array}{c}1.396 \\
(2.872)\end{array}$ & $\begin{array}{c}0.114 \\
(1.920)\end{array}$ & $\begin{array}{c}1.675 \\
(2.749)\end{array}$ \\
\hline \multirow{2}{*}{$\begin{array}{l}\text { Middle East/ } \\
\text { Africa }\end{array}$} & & -0.410 & & & 0.067 & & & $-22.264 *$ & \\
\hline & & $(0.559)$ & & & $(0.413)$ & & & (13.417) & \\
\hline $\begin{array}{c}\text { East \& } \\
\text { South Asia }\end{array}$ & & -0.271 & & & -0.396 & & & -17.346 & \\
\hline & & $(0.587)$ & & & $(0.356)$ & & & $(15.229)$ & \\
\hline British Heritage & & & $\begin{array}{c}0.384 \\
(0.445)\end{array}$ & & & $\begin{array}{c}0.319 \\
(0.223)\end{array}$ & & & $\begin{array}{c}10.487 \\
(11.914)\end{array}$ \\
\hline Obs & 66 & 66 & 66 & 69 & 69 & 69 & 66 & 66 & 66 \\
\hline OIR & 0.936 & 0.809 & 0.981 & 0.905 & 0.964 & 0.748 & 0.648 & 0.814 & 0.592 \\
\hline Endog(FRAC) & $0.013^{* *}$ & $0.006 * * *$ & $0.010^{* *}$ & $0.075^{*}$ & $0.032 * *$ & $0.069^{*}$ & $0.028 * *$ & $0.022 * *$ & $0.024 * *$ \\
\hline Endog(GINI) & 0.395 & 0.466 & 0.298 & 0.602 & 0.998 & 0.717 & 0.428 & 0.862 & 0.272 \\
\hline FS P-Value (FRAC) & 0.135 & 0.115 & $0.044 * *$ & 0.150 & 0.128 & $0.051 * *$ & $0.090 *$ & 0.124 & $0.031 * *$ \\
\hline $\begin{array}{c}\text { FS P-Value } \\
\text { (INC) }\end{array}$ & 0.221 & $0.079^{*}$ & 0.189 & 0.190 & $0.078^{*}$ & 0.157 & 0.271 & 0.102 & 0.228 \\
\hline
\end{tabular}

Robust standard errors in parentheses. $* * * \mathrm{p}<0.01, * * \mathrm{p}<0.05,{ }^{*} \mathrm{p}<0.1$. Endog is the $\mathrm{p}$-value of the test for the endogeneity of the instruments. Under the null hypothesis, the instruments can actually be treated as exogenous. All regressions include a constant (not shown). OIR is the Hansen's J test of the exclusion restriction. FS P-Value is the P-value from the first stage regressions. GINI is the gini coefficient. GINI is the gini coefficient. INCSHARE is the income share of the richest quintile. FRAC is ethno-lingual fractionalization. The instruments are LWHEATSGUAR, the commodity exporting dummy and Latitude. The sample is restricted to former colonies. 
Table 8: Results with Exogenous Inequality

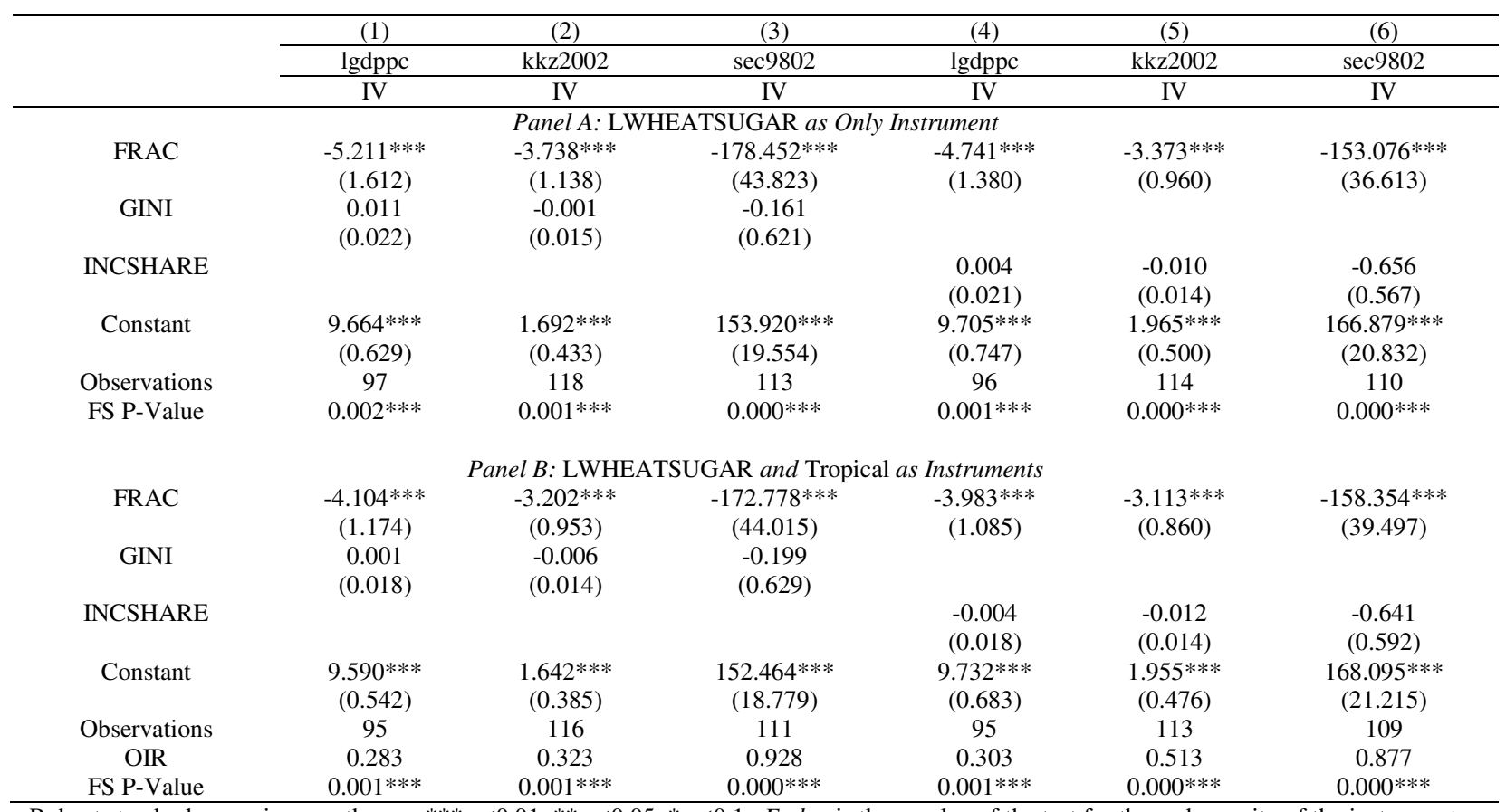

Robust standard errors in parentheses. $* * * \mathrm{p}<0.01, * * \mathrm{p}<0.05, * \mathrm{p}<0.1$. Endog is the $\mathrm{p}$-value of the test for the endogeneity of the instruments. Under the null hypothesis, the instruments can actually be treated as exogenous. All regressions include a constant (not shown). OIR is the Hansen's J test of the exclusion restriction. FS P-Value is the P-value from the first stage regressions. GINI is the gini coefficient. GINI is the gini coefficient. INCSHARE is the income share of the richest quintile. FRAC is ethno-lingual fractionalization. FRAC is the only endogenous variable. 


\section{Appendix Table 1: Variable Definitions}

\begin{tabular}{|c|c|c|}
\hline Variable & Definition & Original Source \\
\hline FRAC & $\begin{array}{l}\text { Probability that two randomly selected individuals } \\
\text { will be from different entho-linguistic groups }\end{array}$ & Alesina et al (2003) \\
\hline INCSHARE & $\begin{array}{c}\text { Income Share of the Richest Quintile. } \\
\text { Averaged 1960-1998 }\end{array}$ & WIDER (2000) \\
\hline GINI & Gini Coefficient. Averaged 1960-1998. & WIDER (2000) \\
\hline $\operatorname{lgdppc}$ & Real GDP per capita in 2002 & WDI and PWT \\
\hline kkz2002 & Institutional Quality Index & Kauffman, Kraay and Zoibo (2002) \\
\hline $\sec 9802$ & Secondary School Enrollment Rate & WDI \\
\hline voice 2002 & $\begin{array}{l}\text { "Voice and Accountability" score. } \\
\text { Standard normal distribution }\end{array}$ & Kauffman, Kraay and Zoibo (2002) \\
\hline polstab2002 & $\begin{array}{l}\text { "Political Stability" score. } \\
\text { Standard normal distribution }\end{array}$ & Kauffman, Kraay and Zoibo (2002) \\
\hline govteff 2002 & $\begin{array}{l}\text { "Government Efficiency" score. } \\
\text { Standard normal distribution }\end{array}$ & Kauffman, Kraay and Zoibo (2002) \\
\hline regqual2002 & $\begin{array}{l}\text { "Regulation Quality" score. } \\
\text { Standard normal distribution }\end{array}$ & Kauffman, Kraay and Zoibo (2002) \\
\hline rulelaw2002 & $\begin{array}{l}\text { "Rule of Law" score. } \\
\text { Standard normal distribution }\end{array}$ & Kauffman, Kraay and Zoibo (2002) \\
\hline corrupt 2002 & "Corruption" score. Standard normal distribution. & Kauffman, Kraay and Zoibo (2002) \\
\hline LWHEATSUGAR & $\begin{array}{l}\log (1+\text { area of land suitable for growing wheat/ } \\
1+\text { area of land suitable for growing sugar })\end{array}$ & FAO (2005) \\
\hline tropical & Share of Arable Land in the Tropics & Sachs and Warner (1997) \\
\hline commod & Commodity exporting Dummy & Easterly (2001) \\
\hline British Heritage & Legal Heritage Dummy & La Porta et al (1998) \\
\hline French Heritage & Legal Heritage Dummy & La Porta et al (1998) \\
\hline Soc. Heritage & Legal Heritage Dummy & La Porta et al (1998) \\
\hline Middle East/ Africa & Continent Dummy & \\
\hline East \& South Asia & Continent Dummy & \\
\hline Europe/ Central Asia & Continent Dummy & \\
\hline Western Hem. & Continent Dummy & \\
\hline
\end{tabular}

All variables are taken from Easterly (2007). 
Appendix Table 2: Summary Statistics

\begin{tabular}{cccccc}
\hline & Obs & Mean & Std. Dev. & Min. & Max. \\
\hline FRAC & 127 & 0.427 & 0.246 & 0.002 & 0.930 \\
INCSHARE & 129 & 46.640 & 8.687 & 17.573 & 71.211 \\
GINI & 135 & 42.046 & 9.003 & 23.970 & 67.458 \\
lgdppc & 107 & 7.924 & 1.004 & 5.802 & 9.625 \\
kkz2002 & 128 & 0.085 & 0.784 & -1.515 & 1.632 \\
sec9802 & 120 & 72.073 & 34.763 & 5.672 & 162.579 \\
voice2002 & 128 & 0.085 & 0.962 & -2.118 & 1.719 \\
polstab2002 & 128 & -0.014 & 0.994 & -2.036 & 1.627 \\
govteff2002 & 128 & 0.096 & 1.021 & -1.638 & 2.262 \\
regqual2002 & 128 & 0.140 & 0.982 & -2.312 & 1.928 \\
rulelaw2002 & 128 & 0.058 & 1.013 & -1.703 & 2.030 \\
corrupt2002 & 128 & 0.046 & 1.056 & -1.427 & 2.393 \\
LWHEATSUGAR & 118 & 0.105 & 0.205 & -0.393 & 0.578 \\
tropical & 121 & 0.310 & 0.403 & 0 & 1 \\
commod & 130 & 0.215 & 0.413 & 0 & 1 \\
British Heritage & 122 & 0.303 & 0.462 & 0 & 1 \\
French Heritage & 122 & 0.426 & 0.497 & 0 & 1 \\
Soc. Heritage & 122 & 0.197 & 0.399 & 0 & 1 \\
Middle East/ Africa & 128 & 0.297 & 0.459 & 0 & 1 \\
East \& South Asia & 128 & 0.188 & 0.392 & 0 & 1 \\
Europe/ Central Asia & 128 & 0.305 & 0.462 & 0 & 1 \\
Western Hem. & 128 & 0.211 & 0.410 & 0 & 1 \\
\hline
\end{tabular}

